\title{
Blockade of cardiac and renal beta-receptors by low dose propranolol in normal subjects Clues to its antihypertensive effect
}

\author{
ROY DAVIES, 1 THOMAS G. PICKERING, ALBERTO MORGANTI, \\ MAXIM WILSON, AND JOHN H. LARAGH
}

From Cardiovascular Center, New York Hospital, 525 East 68th Street, NY 10021, New York, USA

SUMMARY We studied the effects of oral propranolol administered in 2 low dose schedules $(5$ or $20 \mathrm{mg}$ 8 hourly) and for a short term ( 30 to 36 hours) on heart rate, plasma renin activity, and arterial pressure, both at rest and after an isoprenaline challenge $(8 \mathrm{mg}$ i.v. over $2 \mathrm{~min}$ ) in 6 normal subjects. Resting heart rate, plasma renin activity, and systolic pressure all fell significantly after the $5 \mathrm{mg}$ dose and only small additional falls were observed when the dose was increased to $20 \mathrm{mg}$. The fall of diastolic pressure was not significant with $5 \mathrm{mg}$, but was significant with $20 \mathrm{mg}$. That beta-blockade occurred with these low doses was confirmed by diminished responses to isoprenaline. The isoprenaline-induced changes of heart rate, plasma renin activity, and diastolic pressure were reduced by 77, 80, and 65 per cent, respectively, by the $5 \mathrm{mg}$ dose of propranolol, and by 89,94 , and 87 per cent by the $20 \mathrm{mg}$ dose, suggesting that cardiac and renal receptors are equally sensitive to propranolol.

These data indicate a rapid blood pressure lowering action of low dose propranolol in normal subjects and suggest that this effect is in part at least a consequence of blockade of renal and/or cardiac betareceptors. Our results also raise the possibility that much lower doses of propranolol than generally used may be clinically effective.

Despite the widespread use of beta-blockers in the treatment of hypertension, the exact mechanism by which they lower arterial pressure remains obscure. Some have argued that their action is attributable to the blockade of beta-receptors in the heart (Frohlich et al., 1968; Pritchard, 1970) or in the kidneys (Bühler et al., 1972; Casterfors et al., 1973), while others have suggested that their action in hypertension results from effects not directly caused by beta-blockade, such as baroreceptor resetting (Pritchard and Gillam, 1969) or an action on the central nervous system (Offerhaus and Van Zweiten, 1974; Myers et al., 1975). In support of the last two views are studies that indicate delay in the onset of the hypertensive relative to the beta-blocking effects (Pritchard, 1970) and studies suggesting that the hypotensive effect is only seen at doses considerably greater than those required to block peripheral beta-

${ }^{1}$ Present address : Cardiac Department, Whittington Hospital, London N19.

Received for publication 7 June 1978 receptors (Zacharias, 1969; Michelakis and McAllister, 1972). There is very little information as to whether administration of propranolol can lower blood pressure in normotensive individuals, though recent reports have indicated that it may (Le Winter et al., 1975; Miller et al., 1975). In this present study we have administered propranolol in low doses and for a short term to normal subjects, to examine the effects of blockade of peripheral betareceptors on arterial pressure, and have assessed the degree of beta-blockade by a standardised isoprenaline test (Davies et al., 1977).

\section{Subjects and methods}

Six normal subjects who gave their informed consent participated. They were aged 26 to 35 years, were in good physical health, and on no medication. They were studied supine on 4 occasions at approximately the same time in the afternoon; the order in which the first 3 studies were conducted was randomised, while in each subject in a fourth study resting heart 
rate and arterial pressure only were determined. At least 7 days elapsed between studies. The basic procedure was similar for each study; the subjects lay supine in a quiet environment; a slow intravenous infusion of 0.9 per cent saline was established in a left arm vein to facilitate blood sampling and the infusion of isoprenaline. The subjects rested for 30 minutes with the infusion in situ; during the last 5 to 10 minutes heart rate and sphygmomanometrically measured arterial pressure were determined at 1 to 2 minute intervals until a steady baseline was established. Korotkof sounds I and IV were used to determine systolic and diastolic pressures, respectively, and the same mercury sphygmomanometer was used throughout. All measurements of heart rate and arterial pressure were made by the laboratory nurse who was unaware of the dosing sequence. A control sample for plasma renin activity was taken and then an infusion of $8 \mu \mathrm{g}$ isoprenaline diluted in $10 \mathrm{ml}$ saline was administered slowly by hand over 2 minutes. Heart rate and arterial pressure were determined at 1 minute intervals for 6 minutes and at 2 to 3 minute intervals for a further 15 minutes. Further samples for plasma renin activity were taken $5,10,15$, and 20 minutes after the beginning of the isoprenaline infusion. In the studies with propranolol, either 5 or $20 \mathrm{mg}$ was administered beginning at 7 to 8 a.m. of the day before study; medication was taken 8-hourly for a total of 5 doses, the last dose being taken some 90 minutes before study. A 24-hourly urine collection was made from noon of the day before study until noon of the study day.

Plasma renin activity was determined as previously described (Sealey and Laragh, 1975) and urinary sodium was determined by flame photometry.

\section{DETERMINATION OF RESTING HEART RATE AND BLOOD PRESSURE}

The means of at least 4 determinations of heart rate, systolic and diastolic pressure observed in the first control study were used to determine the resting values. The values so obtained were then compared with similar values obtained in the fourth study. If these mean values differed by more than 4 beats/min or by more than $4 \mathrm{mmHg}$, then the mean of the mean values so determined was used in subsequent calculations.

\section{STATISTICS}

Results are expressed as mean \pm SEM and are analysed by Student's $t$ test for paired data, each subject providing his own control basal and isoprenaline response data. The percentage reduction of the isoprenaline response is calculated by com- paring the responses of heart rate and plasma renin activity on propranolol with that subject's control response.

\section{Results}

Neither propranolol nor isoprenaline resulted in any untoward effect in any subject. In the control study the subjects experienced mild palpitation and throbbing of the trunk, symptoms which were diminished considerably by both doses of propranolol.

EFFECT OF PROPRANOLOL ON BASAL VALUES (Fig.)

The mean control systolic pressure of $120 \pm 6.5$ $\mathrm{mmHg}$ was significantly $(\mathrm{t}=7.01, \mathrm{P}<0.001)$ reduced to $114 \pm 6 \mathrm{mmHg}$ by the $5 \mathrm{mg}$ dose, and to $109 \pm 7 \mathrm{mmHg}$ by the $20 \mathrm{mg}$ dose $(\mathrm{t}=3.42, \mathrm{P}<$ $0.01)$. The decrease of diastolic pressure from $71.5 \pm 2 \mathrm{mmHg}$ to $67 \pm 4 \mathrm{mmHg}$ with the $5 \mathrm{mg}$ dose was not significant, but the fall to $61.5 \mathrm{mmHg}$ with the $20 \mathrm{mg}$ dose $(t=4.24, P<0.01)$ was significant. Heart rate fell from $72.0 \pm 1.5$ beats $/ \mathrm{min}$ to $61 \pm 1.5$ beats $/ \mathrm{min}$ with the $5 \mathrm{mg}$ dose $(t=9.83$, $P<0.001)$ and to $58 \pm 3.5$ with $20 \mathrm{mg}(t=4.17$, $P<0.01)$. Plasma renin activity fell from $3.1 \pm$ $0.7^{1} \mu \mathrm{g} / \mathrm{h}$ per 1 to $1.8 \pm 0.4 \mu \mathrm{g} / \mathrm{h}$ per 1 with the $5 \mathrm{mg}$ dose $(t=2.17, P<0.05)$ and to $1.6 \pm 0.7$ $\mu \mathrm{g} / \mathrm{h}$ per 1 with the $20 \mathrm{mg}$ dose $(t=5.42, P<$ $0.001)$. Urinary sodium excretion and serum potassium were unaffected by propranolol.

\section{EFFECTS OF PROPRANOLOL ON RESPONSE TO} ISOPRENALINE

In the control study, the mean increase in heart rate after isoprenaline was $43 \pm 5$ beats $/ \mathrm{min}$; after propranolol the mean increase was only $10 \pm 2$ beats $/ \mathrm{min}$ for the $5 \mathrm{mg}$ dose and $4.5 \pm 1$ beats $/ \mathrm{min}$ for the $20 \mathrm{mg}$ dose $(5 \mathrm{mg}$ and $20 \mathrm{mg}$ vs control, $t=6.47$ and 6.63 , respectively, $P<0.001$ for each, $5 \mathrm{mg}$ vs. $20 \mathrm{mg}, \mathrm{t}=2.69, \mathrm{P}<0.025$ ). The mean increase in plasma renin activity in the control study was $3.6 \pm 1 \mu \mathrm{g} / \mathrm{h}$ per 1 . This fell to $0.7 \pm 0.1 \mu \mathrm{g} / \mathrm{h}$ per 1 after the $5 \mathrm{mg}$ dose $(\mathrm{t}=3.03, \mathrm{P}<0.025)$ and to $0.2 \pm 0.01 \mu \mathrm{g} / \mathrm{h}$ per 1 after the $20 \mathrm{mg}$ dose (control vs. $20 \mathrm{mg}, \mathrm{t}=3.61, \mathrm{P}<0.01$ ). The response after the $20 \mathrm{mg}$ dose was significantly less than that after $5 \mathrm{mg}(\mathrm{t}=6.5, \mathrm{P}<0.001)$. The mean isoprenaline-induced fall of diastolic pressure was $24 \pm 4 \mathrm{mmHg}$ in the control study; this was significantly attenuated to $8.5 \pm 2 \mathrm{mmHg}(\mathrm{t}=3.1$, $P<0.025)$ by the $5 \mathrm{mg}$ dose of propranolol, and further to $3 \pm 1 \mathrm{mmHg}$ by the $20 \mathrm{mg}$ dose. The

$11 \mu \mathrm{g} / \mathrm{h}$ per $1 \approx 0.77 \mathrm{nmol} / \mathrm{h}$ per 1 . 


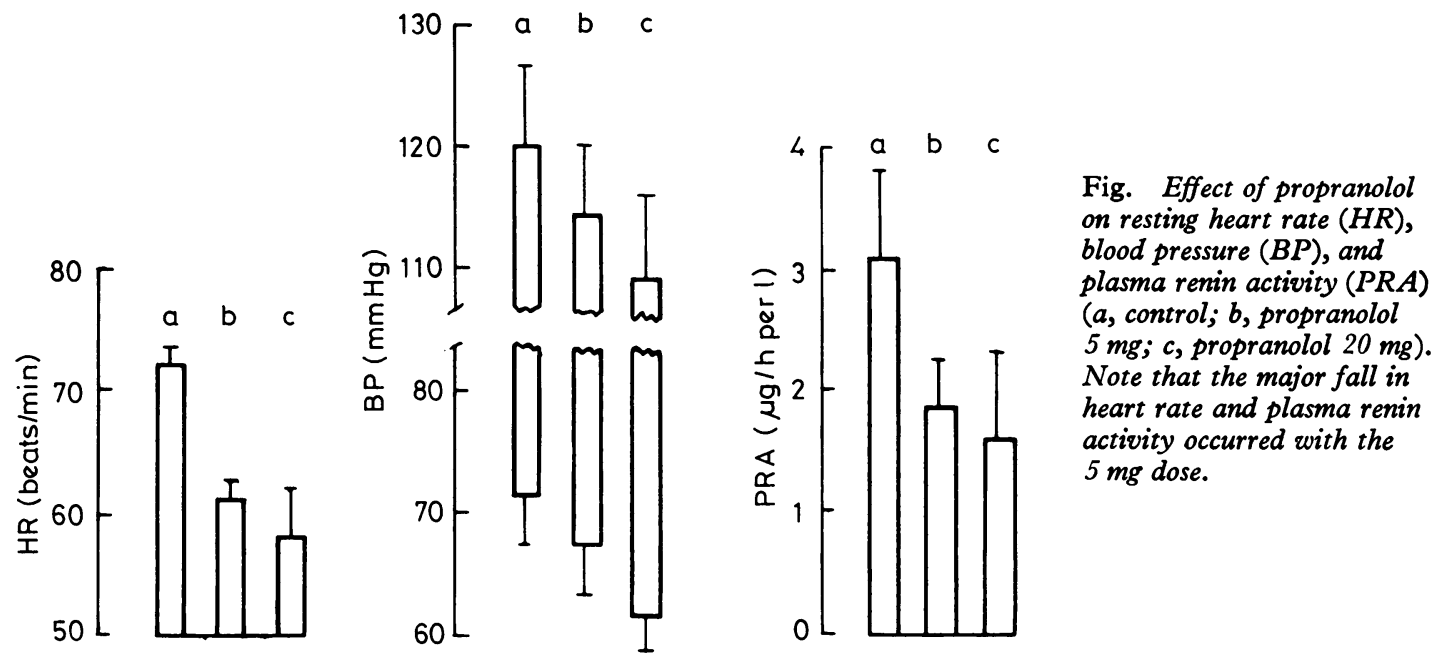

mean percentage reduction of the isoprenalineinduced changes of heart rate and plasma renin activity observed with the doses of propranolol employed amount to $77 \pm 6$ per cent and $89 \pm$ 4 per cent, respectively, for heart rate ( 5 vs. 20 , $t=2 \cdot 19, P<0.5)$ and to $80 \pm 6$ per cent and $94 \pm 1$ per cent, respectively for plasma renin activity ( 5 vs. $20, t=9, P<0.025$ ). The corresponding values for the blockade of diastolic pressure were $65 \pm 11$ per cent and $87 \pm 4$ per cent, respectively.

\section{Discussion}

This study describes some interesting, heretofore unrecognised, effects of low dose propranolol in normal subjects. Of particular interest is the effect of propranolol in a dose of only $5 \mathrm{mg} 8$-hourly (15 $\mathrm{mg}$ daily) in lowering both resting heart rate and plasma renin activity. Indeed, when the dose was increased fourfold to $20 \mathrm{mg}$ 8-hourly ( $60 \mathrm{mg}$ daily), only small additional falls in these variables were observed, suggesting that large, and possibly near maximal, blockade of resting heart rate and plasma renin activity can be obtained at very low doses of propranolol. This possibility is strengthened by the observation that 75 per cent or more of the isoprenaline-induced changes of heart rate and plasma renin activity are blocked by this dose. Consonant with this finding is the study of Leonetti et al. (1975) who treated patients with hypertension with propranolol in increasing doses from 40 to $160 \mathrm{mg}$ daily. They found that near maximal falls of resting heart rate and of plasma renin activity were achieved at the $40 \mathrm{mg} /$ day dose, which was the lowest dose they studied, there being relatively small additional falls when the dose of propranolol was increased stepwise to $160 \mathrm{mg}$ daily. A further point of interest is the effect of propranolol on arterial pressure, a change that followed closely those of heart rate and plasma renin activity. Thus, systolic pressure fell by $6 \mathrm{mmHg}$ on the lower dose and $11 \mathrm{mmHg}$ on the higher, and similarly diastolic pressure fell on both doses. Our results, therefore, show that propranolol given in low doses can lower arterial pressure in normal subjects, and that this effect occurs within 36 hours.

A potential criticism of our study is that the small falls of arterial pressure that we have observed might be the result of a placebo effect or of observer bias. However, the order in which the studies were conducted was randomised to minimise these effects and the nurse-observer was unaware of the dosing sequence. Furthermore, the basal values of heart rate and arterial pressure were checked in the fourth study when no drugs were administered and no blood drawn. Indeed the extent of the falls of these variables with these doses was quite unexpected, and the effects on resting plasma renin activity and on the isoprenaline responses are unlikely to be susceptible to placebo effects or to observer bias. Furthermore, other workers have reported falls of arterial pressure in normal subjects. Thus, Le Winter et al. (1975) found a small but significant fall in arterial pressure after the administration of propranolol (160 mg daily for 2 weeks) to normal young subjects, and Miller et al. (1975) found that blood pressure fell significantly in normotensive patients who were receiving propranolol for angina 
pectoris. In the context of these earlier studies, our results extend this observation to a lower dose level.

To what extent does this study clarify our understanding of the mechanisms by which propranolol lowers arterial pressure ? By using very small doses of propranolol administered short term, it can be assumed that the site of action is limited to peripheral beta-receptors, since it is generally agreed that such blood pressure lowering effect as propranolol may have, due to a central action, is seen with relatively large doses (Hollifield et al., 1975). In common with Leonetti et al. (1975) we have observed striking reductions of heart rate and plasma renin activity after doses of propranolol far below those required to exert an effect on the central nervous system (Offerhaus and Van Zweiten, 1974; Hollifield et al., 1975). Moreover, in the present study these effects were accompanied by a small but significant fall of arterial pressure, and it seems probable that this is also a consequence of peripheral beta-blockade. Two possible mechanisms have been proposed to explain this blood pressure lowering effect: first, by blockade of cardiac receptors, reducing heart rate and cardiac output, and secondly, by blockade of renal receptors reducing plasma renin activity. The blood pressure lowering effect of propranolol has been attributed to a reduction of cardiac output by a number of groups (Ulrych et al., 1968; Johnsson et al., 1969; Pritchard et al., 1970; Sannerstedt et al., 1970), though more recently the Cleveland group, who were the main proponents of this view, have found that the antihypertensive response was predictable neither by control measurements of cardiac function nor by changes in cardiac function induced by propranolol therapy (Tarazi and Dustan, 1972). The alternative view, that propranolol's antihypertensive effect is mediated by its renin-lowering action, was first suggested by Bühler et al. (1972). While this view has been supported by several studies (Casterfors et al., 1973; Hansson and Zweifler, 1974), it has been contested by others (Birkenhäger et al., 1971; Stokes et al., 1974; Bravo et al., 1975). An argument that has figured prominently in opposing the view that propranolol can lower blood pressure by its reninlowering action is the apparent temporal dissociation between the fall of plasma renin activity, which occurs early, and the fall of arterial pressure, which some workers have suggested is delayed (Frohlich et al., 1968; Pritchard, 1970). Manifestly this is not necessarily the case, as has been shown in this and other studies (Ulrych et al., 1972; Leonetti et al., 1975; Fitzgerald, 1976; Stumpe et al., 1976; Taylor et al., 1976). Similarly, the view held by some workers (Pritchard and Gillam, 1969; Zacharias, 1969; Michelakis and McAllister, 1972) that a higher dose of propranolol is required for the antihypertensive effect compared with the reninlowering effect, which has also been used as evidence against these effects being related, is not supported by our study or by that of Leonetti et al. (1975). While this present study in no way excludes a second influence at high doses, it does define a close association between the blood pressure lowering effect of propranolol and peripheral betablockade. The relative contributions of the effects on cardiac and renal receptors require further dissection.

R.D. was in receipt of a Wellcome Research Travel Grant and of the Berkeley Fellowship.

\section{References}

Birkenhäger, W. H., Krauss, X. H., Schalekamp, M. A. D. H., Kolsters, G., and Kroom, B. J. M. (1971). Antihypertensive effect of propranolol. Folia Medica Neerlandica, 14, 67-71.

Bravo, E. L., Tarazi, R. C., and Dustan, H. P. (1975). $\beta$-adrenergic blockade in diuretic treated patients with essential hypertension. New England fournal of Medicine, 292, 66-70.

Bühler, F. R., Laragh, J. H., Baer, L., Vaughan, E. D., Jr., and Brunner, H. R. (1972). Propranolol inhibition of renin secretion. New England fournal of Medicine, 287, 1209-1214.

Casterfors, J., Johnsson, H., and Orö, L. (1973). Effect of alprenolol on blood pressure and plasma renin activity in hypertensive patients. Acta Medica Scandinavica, 193, 189-195.

Davies, R., Slater, J. D. H., Rudolf, M., and Geddes, D. M. (1977). The effect of isoprenaline on plasma renin activity in man: a dose response curve. Clinical Endocrinology, 6, 395-399.

Fitzgerald, J. D. (1976). Beta blockade and mechanisms of disease. Postgraduate Medical fournal, 52, Suppl. 4, 184-190.

Frohlich, E. D., Tarazi, R. C., Dustan, H. P., and Page, I. H. (1968). The paradox of beta-adrenergic blockade in hypertension. Circulation, 37, 417-423.

Hansson, L., and Zweifler, A. M. (1974). The effect of propranolol on plasma renin activity and blood pressure in mild essential hypertension. Acta Medica Scandinavica, 195, 397-401.

Hollifield, J. W., Sherman, K., Van der Zwagg, R., and Shand, D. (1975). Proposed mechanisms of propranolol's antihypertensive effect in essential hypertension. New England fournal of Medicine, 295, 68-73.

Johnsson, G., de Guzman, M., and Bergman, H. (1969). The haemodynamic effects of alprenolol and propranolol at rest and during exercise. Pharmacologia Clinica, 2, 34-39.

Leonetti, G., Mayer, G., Morganti, A., Terzoli, L., Zanchetti, A., Bianchetti, G., Di Salle, E., Morselli, P., and Chidsey, C. A. (1975). Hypotensive and renin-suppressing activities of propranolol in hypertensive patients. Clinical Science and Molecular Medicine, 48, 491-499.

Le Winter, M., Crawford, M. H., Karliner, I. S., and O'Rourke, R. A. (1975). Effects of oral propranolol in normal subjects. Clinical Pharmacology and Therapeutics, 17, 709-712.

Michelakis, A. M., and McAllister, R. G. (1972). The effect of chronic adrenergic blockade on plasma renin activity in man. fournal of Clinical Endocrinology and Metabolism, 34, 386-394. 
Miller, R. R., Olson, H. G., Pratt, C. M., Amsterdam, E. A., and Mason, D. T. (1975). Efficacy of beta-adrenergic blockade in coronary heart disease: propranolol in angina pectoris. Clinical Pharmacology and Therapeutics, 18, 598-604.

Myers, M. G., Lewis, P. J., Reid, J. L., and Dollery, C. T. (1975). Brain concentration of propranolol in relation to hypotensive effect in the rabbit with observations on brain propranolol levels in man. Fournal of Pharmacology and Experimental Therapeutics, 192, 327-335.

Offerhaus, L., and Van Zweiten, P. A. (1974). Comparative studies on central factors contributing to the hypotensive action of propranolol, alprenolol, and their enantiomers. Cardiovascular Research, 8, 488-495.

Pritchard, B. N. C. (1970). Propranolol as an antihypertensive agent. American Heart fournal, 79, 128-133.

Pritchard, B. N. C., and Gillam, P. M. S. (1969). Treatment of hypertension with prepranolol. British Medical Fournal, 1, 7-16.

Pritchard, B. N. C., Shinebourne, E., Fleming, J., and Hamer, J. (1970). Haemodynamic studies in hypertensive patients treated by oral propranolol. British Heart fournal, 32, 236-240.

Sannerstedt, R., Julius, S., and Conway, J. (1970). Hemodynamic responses to tilt and beta-adrenergic blockade in young patients with borderline hypertension. Circulation, 42, 1057-1064.

Sealey, J. E., and Laragh, J. H. (1975). Radioimmunoassay of plasma renin activity. Seminars in Nuclear Medicine, 5, 189-202.
Stokes, G. S., Weber, M. R., and Thornell, I. R. (1974). $\beta$-blockers and plasma renin activity in hypertension. British Medical fournal, 1, 60-62.

Stumpe, K. O., Kolloch, R., Vetter, H., Gramman, W., Krück, F., Ressel, C., and Higuchi, M. (1976). Acute and long term studies of the mechanism of action of beta blocking drugs in lowering blood pressure. American fournal of Medicine, 60, 853-865.

Tarazi, R. C., and Dustan, H. P. (1972). Beta-adrenergic blockade in hypertension: practical and theoretical implications of long-term hemodynamic variations. American fournal of Cardiology, 29, 633-640.

Taylor, S. W., Davidson, C., Singleton, W., and Thadani, U. (1976). Comparison of antihypertensive effectiveness of beta-adrenoreceptor antagonists with different pharmacological properties. British Heart fournal, 38, 313.

Ulrych, M., Franciosa, J., and Conway, J. (1972). Comparison of a new beta-adrenergic blocker (MK 950) and propranolol in man. Clinical Pharmacology and Therapeutics, 13, 232-238. Ulrych, M., Frohlich, E. D., Dustan, H. P., and Page, I. H. (1968). Immediate hemodynamic effects of beta-adrenergic blockade with propranolol in normotensive and hypertensive man. Circulation, 37, 411-416.

Zacharias, F. J. (1969). Treatment of hypertension with propranolol. British Medical fournal, 1, 712.

Requests for reprints to Dr R. Davies, Whittington Hospital, Islington, London N19 5NF. 